\title{
Vestibular evoked myogenic potential: its use in Sudden Sensorineural Hearing Loss
}

\author{
Alleluia Lima Losno Ledesma \\ Monique Antunes de Souza Chelminski Barreto ${ }^{3}$ \\ Fayez Bahmad Jr²
}

\begin{abstract}
Introduction: Sudden sensorineural hearing loss (SHL) has uncertain origin and evolution. Vestibular evoked myogenic potential (VEMP) estimates of the vestibular pathway that can not be analyzed by the other entrance examinations, which can be helpful in diagnosing the extent of hearing damage in these patients. Objectives: To investigate the clinical applicability of VEMP in patients with SHL. Methods: This is a systematic review. Searches were conducted in the databases PubMed/Medline, SciELO and LILACS. Data were tabulated. Results: We found 45 articles, 15 of these made up the study by fitting either the inclusion factors. The objective of $60 \%$ of the studies was to determine whether the VEMP can be used as predictive hearing recovery Conclusion: VEMP may be useful as hearing recovery predictor in patients with sudden sensorineural hearing loss, justifying the implementation of such examination in this population.
\end{abstract}

Keywords: deafness, hearing loss, sudden, vestibular evoked myogenic potentials.

\footnotetext{
${ }^{1}$ Fonoaudióloga da Secretaria de Saúde do GDF, mestranda em Ciências da Saúde pela Universidade de Brasília.

2 Professor e Orientador do Programa de Pós Graduação em Ciências da Saúde da Universidade de Brasília (UnB-DF). Médico Otorrinolaringologista do Hospital Universitário de Brasília (HUB-UnB) - Universidade de Brasilia - Brasilia - DF - Brasil.

${ }^{3}$ Fonoaudióloga do Governo do Distrito Federal (GDF), Mestre em Ciências da Saúde (UnB-DF) e Doutoranda em Ciências da Saúde (UnB-DF). - Universidade de Brasília (UnB) - Brasilia - DF - Brasil.

Institution: Universidade de Brasilia (UnB)

Send correspondence to:

Fayez Bahmad Jr

SMHN Qd 02 Bloco C, Ed. Dr. Crispim, Sala 515, Asa Norte, Brasilia - DF, Brasil. Zip Code: 70710-149. fayezbjr@gmail.com

Paper submitted to the ITJ-SGP (Publishing Management System) on December 21, 2014;

and accepted on March 19, 2015. cod. 184
} 


\section{INTRODUCTION}

Sudden sensorineural hearing loss or sudden deafness is characterized as a hearing loss of abrupt onset, usually unilateral, with no known cause. May be impairment of the inner ear and/or central auditory pathways, intensity and variable frequencies, ranging from mild ear fullness to total hearing loss, which is accompanied by tinnitus and dizziness in approximately $80 \%$ and $40 \%$ of cases, respectively ${ }^{1-3}$.

It's an emergency in otology and affects mainly the fourth decade of life and affects 5 to 20 people out of 100 thousand individuals per year and it is estimated that there are about 4000 new cases per year in the United States and 15,000 worldwide, with equal distribution in relation to gender ${ }^{46}$.

They are hypotheses to explain the etiology of sudden deafness as the vascular hypothesis, viral hypothesis, the autoimmune hypothesis and the membrane rupture hypothesis. However, the current trend is to consider the sudden hearing loss as a disease of multifactorial etiology'.

The Vestibular Evoked Myogenic Potential is an electrophysiological test that evaluates the goal via spinal hall. The eliciting stimulus can be audible (click) or galvanic, activating the saccular macula and triggering the reflex pathway lowest labial nerve, lateral vestibular nucleus, spinal tract hall and finally ipsilateral motor neuron, being picked up by surface electrodes arranged on the sternocleidomastoid muscle 7,8 .

The history of this examination is relatively recent as though their first date back to 1964 reports, only in 1994 were published the first studies suggesting clinical application for Evoked Myogenic. The number of publications has increased considerably since 2000. Currently its route and method are well defined and the latter studies devoted to clinical applications 9 .

For review of the vestibular pathway that cannot be analyzed by the other entrance exams, the exam has been gaining attention in the labial battery evaluation. Despite this, few studies have been published focusing on the Vestibular Evoked Myogenic Potential in inner ear disorders such as sudden deafness ${ }^{10}$.

\section{OBJECTIVES}

The aim of this study was to investigate the clinical applicability of Vestibular Evoked Myogenic Potentials in patients with sudden sensorineural hearing loss.

\section{MATERIAL AND METHODS}

This is a systematic review that followed the precepts of the Cochrane Handbook ${ }^{11}$ as the formulation of the question, location, selection and critical evaluation of the articles. The research was funded by the following question: "The Vestibular Evoked Myogenic Potential is useful in the diagnosis of patients with sudden sensorineural hearing loss?"

Searches were conducted in the databases PubMed/MedLine, SciELO and LILACS.

Using the extracted descriptors of Medical Subject Headings (MeSH), was established the following advanced search strategy in PubMed, 'vestibular evoked myogenic potentials' associated by the Boolean operator AND to 'hearing loss, sudden'.

In the LILACS and SciELO database, we used the indexed descriptors Descriptors in Health Sciences (MeSH), according to the following strategy: Perda auditiva súbita AND Potenciais evocados.

It was considered as inclusion criteria articles in English, Portuguese or Spanish, published in the last two decades that associate sudden sensorineural hearing loss and vestibular evoked myogenic potentials. Was excluded from letters to the editor and duplicated text.

Abstracts of pre-selected articles were assessed by two reviewers, were selected for analysis those correlated descriptors. Where there was disagreement, a third reviewer was triggered.

Data were tabulated covering the following information: authors, place and year of publication, sample size (n), objectives and type of study (Table 1).

\section{RESULTS}

The 45 articles found, 11 were excluded due to language, to be present at duplicate or not correlate the descriptors. The abstracts of 34 articles were analyzed. Of these, 15 articles were included in the study by fitting either the inclusion factors (Table 2).

About the type of study $53 \%$ were prospective, 6 longitudinal studies ${ }^{10,12-16}$ and two transverse ${ }^{17,18}$, $33 \%$ were restrospectives ${ }^{19-23}, 7 \%$ case study ${ }^{24}$ and $7 \%$ Bayesian cure rate model ${ }^{25}$.

The objective of $60 \%$ of the studies was to determine whether the Vestibular Evoked Myogenic Potential (VEMP) can be used as a predictor of hearing recovery in patients with PANSS ${ }^{10,12-16,19,20,23}$. Of these, $67 \%$ found a positive relationship between the presence of VEMP and the degree of hearing recovery ${ }^{10,13,15,19,20,23}$. Others studies despite having different objectives pointed VEMP as helpful tool in the management of patients with sudden sensorineural hearing loss ${ }^{17,18,21,22,25}$.

Among the studies that have investigated the use of objective tests in the management of patients with PANSS some noteworthy.

Study conducted in Japan, with 22 patients with PANSS and single episode of vertigo, revealed that $77 \%$ and $45 \%$ showed VEMP and caloric test changed, 
Table 1. Analysis of the articles included taking into account the author, place, year of publication, sample size, objectives and type of study

\begin{tabular}{|c|c|c|c|}
\hline Author, place and year of publication & Sample size & Objectives & Type of study \\
\hline $\begin{array}{l}\text { Nagai N, Ogawa Y, Hagiwara A, Otsuka K, } \\
\text { Inagaki T, Shimizu S, et al. Japan, } 2014\end{array}$ & 109 & $\begin{array}{l}\text { To investigate the use of ocular VEMP and } \\
\text { cervical VEMP as hearing recovery predictor }\end{array}$ & Prospective longitudinal \\
\hline $\begin{array}{l}\text { Ogawa Y, Otsuka K, Shimizu S, Inagaki } \\
\text { T, Kondo T, Suzuki M. Japan, } 2012\end{array}$ & 116: $36 \mathrm{VN}, 80 \mathrm{SHL}$ & $\begin{array}{l}\text { To investigate the use of VEMP and caloric } \\
\text { tests as hearing recovery predictor }\end{array}$ & Prospective longitudinal \\
\hline Jung JY, Kim YH, Suh MW Korea, 2012 & 54: 32 VN, 22 SHL & $\begin{array}{l}\text { To investigate the clinical difference of } \\
\text { dizziness in vestibular neuritis and SHL }\end{array}$ & Retrospective \\
\hline $\begin{array}{l}\text { Ryu IS, Yoon TH, Ahn JH, Kang WS, } \\
\text { Choi BS, Lee JH, et al. Korea, } 2011\end{array}$ & 35 & $\begin{array}{l}\text { 3D-FLAIR MRI to Investigate buccal lesions in } \\
\text { Patients with SSNHL }\end{array}$ & Transversal prospective \\
\hline $\begin{array}{l}\text { Korres S, Stamatiou GA, Gkoritsa E, } \\
\text { Riga M, Xenelis J Greece, } 2010\end{array}$ & 104 & $\begin{array}{l}\text { Correlating the results of VEMP with the } \\
\text { caloric test and hearing recovery as predictors }\end{array}$ & Longitudinal prospective \\
\hline Chao TK, Hsiu-Hsi Chen T Taiwan, 2010 & 200 & $\begin{array}{l}\text { To establish a predictive model for evaluating } \\
\text { improvement in patients with SHL }\end{array}$ & Cure rate Bayesian model \\
\hline $\begin{array}{l}\text { Stamatiou G, Gkoritsa E, Xenellis J, } \\
\text { Riga M, Korres S. Greece, } 2009\end{array}$ & 86 & $\begin{array}{c}\text { Correlating the results of VEMP with the } \\
\text { caloric test }\end{array}$ & Transversal Prospective \\
\hline $\begin{array}{l}\text { Wang CT, Huang TW, Kuo SW, Cheng } \\
\text { PW Taiwan; } 2009\end{array}$ & 88 & $\begin{array}{c}\text { To investigate the use of VEMP and ABR } \\
\text { hearing recovery as predictors }\end{array}$ & Retrospective \\
\hline Kang KT, Young YH Taiwan; 2008 & 1 & $\begin{array}{c}\text { Reports a rare case of SHL in patients with } \\
\text { antiphospholipid syndrome }\end{array}$ & Case Study \\
\hline Chao TK; Chen TH Taiwan, 2006 & 108 & $\begin{array}{l}\text { To investigate the use of DPOAE and VEMP as } \\
\text { hearing recovery predictor }\end{array}$ & Longitudinal prospective \\
\hline Iwasaki S, Takai Y, Ito K Japan, 2005 & 811 & $\begin{array}{l}\text { Investigate clinical features of diseases } \\
\text { showing abnormal VEMP responses with } \\
\text { normal caloric test responses }\end{array}$ & Retrospective \\
\hline Kuo YL, Young YH Taiwan, 2012 & 1156 & $\begin{array}{l}\text { To investigate the use of VEMP as hearing reco- } \\
\text { very of prognosis in patients with recurrent SHL }\end{array}$ & Retrospective \\
\hline $\begin{array}{l}\text { Hong SM, Byun JY, Park CH, Lee JH, } \\
\text { Park MS, Cha Cl. Korea, } 2008\end{array}$ & 52 & $\begin{array}{l}\text { To investigate the use of VEMP as hearing } \\
\text { recovery predictor in SHL patients without vertigo }\end{array}$ & Longitudinal Prospective \\
\hline $\begin{array}{l}\text { Iwasaki S, Takai Y, Ozeki H, Ito K, } \\
\text { Karino S, Murofushi T Japan, } 2005\end{array}$ & 22 & $\begin{array}{l}\text { To investigate the use of click-VEMP and } \\
\text { galvanic-VEMP as hearing recovery predictor } \\
\text { in SHL patients with vertigo }\end{array}$ & Retrospective \\
\hline Wu CC, Young YH Taiwan, 2002 & 22 & $\begin{array}{l}\text { To investigate the use of VEMP as hearing } \\
\text { recovery predictor }\end{array}$ & Longitudinal Prospective \\
\hline
\end{tabular}

a) VN: Vestibular Neuritis; b) SHL: Sudden Sensorineural Hearing Loss; c) VEMP: Vestibular Evoked Myogenic Potentials; d) ABR: Auditory Brain Stem Response; e) DPOAE: Distortion Product Otoacoustic Emissions

Table 2. Distribution of articles according to the research strategy

\begin{tabular}{lccc}
\hline Research Strategy & $\begin{array}{c}\text { 'vestibularevoked myogenic } \\
\text { potentials' AND 'hearing loss, } \\
\text { sudden' }\end{array}$ & $\begin{array}{c}\text { 'Sudden hearing loss' AND } \\
\text { 'evoked potentials' }\end{array}$ & $\begin{array}{c}\text { 'Sudden hearing loss' AND } \\
\text { 'evoked potentials' }\end{array}$ \\
\hline Data base & PubMed/MedLine & SciELO & Lilacs \\
Number of articles found & 44 & 01 & 0 \\
Abstract analyzed & 33 & 01 & 0 \\
Articles analyzed & 15 & 0 & 0 \\
\hline
\end{tabular}

respectively. The authors suggest that the sacculus is most often struck in the case of the PANSS the horizontal semicircular canal function and its afferent. They add that the creation of the VEMP associated with caloric test is useful in the evaluation of these patients as they relate to the degree of hearing recovery ${ }^{23}$.

Prognostic factors of patients with PANSS and worse hearing threshold than $70 \mathrm{~dB}$, and its relationship with hearing and vestibular tests were investigated. VEMP and ABR were positively correlated with a better prognosis, reaching $64 \%$ of full recovery in patients with hearing severe hearing loss $^{20}$.

Trying to minimize the uncertainties surrounding the hearing recovery of patients with sudden sensorineural hearing loss was developed a predictive model of evolution by reference audiological tests (audiometry, 
DPOAE, VEMP and ABR) and other variables considered as prognostic factors. The authors conclude that this is a useful method, however, point out that should only be used if the therapy used is the same adopted in the study ${ }^{25}$.

Retrospective study investigated the hearing recovery in patients with recurrent PANSS. Among patients with recurrent ipsilaterally PANSS, all had normal VEMP and had hearing recovery. Since patients with contralateral applicant PANSS, $80 \%$ had altered VEMP, showing no hearing recovery after treatment. It was concluded that VEMP can be used as a prognostic factor in recurrent PANSS in order that their presence would indicate a high probability of hearing recovery ${ }^{19}$.

\section{CONCLUSION}

Many studies have sought to elucidate whether the Vestibular Evoked Myogenic Potential can be a useful predictor of hearing recovery in patients with sudden sensorineural hearing loss, which is a positive relationship in most of them, justifying the implementation of such examination in this population.

\section{REFERENCES}

1. Maia RA, Cahali S. Surdez súbita. Rev Bras Otorrinolaringol. 2004;70(2):238-48. DOI: http://dx.doi.org/10.1590/S003472992004000200015

2. Penido Nde O, Ramos HV, Barros FA, Cruz OL, Toledo RN. Clinical, etiological and progression factors of hearing in sudden deafness. Braz J Otorhinolaryngol. 2005;71(5):633-8.

3. Lazarini PR, Camargo AC. Idiopathic sudden sensorineural hearing loss: etiopathogenic aspects. Braz J Otorhinolaryngol. 2006;72(4):554-61. PMID:17143437

4. Byl FM Jr. Sudden hearing loss: eight years' experience and suggested prognostic table. Laryngoscope. 1984;94(5 Pt 1):647-61. DOI:http://dx.doi.org/10.1288/00005537-198405000-00014

5. Rauch SD. Clinical practice. Idiopathic sudden sensorineural hearing loss. N Engl J Med. 2008;359(8):833-40. DOI:http://dx.doi. org/10.1056/NEJMcp0802129

6. Stachler RJ, Chandrasekhar SS, Archer SM, Rosenfeld RM, Schwartz SR, Barrs DM, et al.; American Academy of Otolaryngology-Head and Neck Surgery. Clinical practice guideline: sudden hearing loss. Otolaryngol Head Neck Surg. 2012;146(3 Suppl):S1-35. PMID: 22383545 DOI:http://dx.doi.org/10.1177/0194599812436449

7. Felipe L, Santos MA, Gonçalves DU. Vestibular evoked myogenic potential (Vemp): evaluation of responses in normal subjects. Pro Fono. 2008;20(4):249-54. DOI: http://dx.doi.org/10.1590/S010456872008000400008

8. Aidar RC, Suzuki FA. Vestibular evoked myogenic potential: new perspectives in multiple sclerosis. Braz $\mathrm{J}$ Otorhinolaryngol. 2005;71(1):48-54. PMID:16446891

9. David R, Colafêmina JF. Potenciais miogênico evocados vestibulares (VEMP): uma revisão bibliográfica. Rev Bras Otorrinolaringol. 2002;68(1):113-7. DOI: http://dx.doi.org/10.1590/S003472992002000100020
10. Nagai N, Ogawa Y, Hagiwara A, Otsuka K, Inagaki T, Shimizu S, et al. Ocular vestibular evoked myogenic potentials induced by bone-conducted vibration in patients with unilateral inner ear disease. Acta Otolaryngol. 2014;134(2):151-8. DOI: http://dx.doi.org/10.31 09/00016489.2013.844361

11. The Cochrane Collaboration. Cochrane handbook for systematic reviews of interventions [Internet]. 2006 [Cited Jun 2, 2015]. Available from: http://community.cochrane.org/sites/default/files/uploads/ Handbook4.2.6Sep2006.pdf

12. Ogawa Y, Otsuka K, Shimizu S, Inagaki T, Kondo T, Suzuki M. Subjective visual vertical perception in patients with vestibular neuritis and sudden sensorineural hearing loss. J Vestib Res. 2012;22(4):205-11.

13. Korres S, Stamatiou GA, Gkoritsa E, Riga M, Xenelis J. Prognosis of patients with idiopathic sudden hearing loss: role of vestibular assessment. J Laryngol Otol. 2011;125(3):251-7. DOI: http://dx.doi. org/10.1017/S0022215110002082

14. Chao TK, Chen TH. Distortion product otoacoustic emissions as a prognostic factor for idiopathic sudden sensorineural hearing loss. Audiol Neurootol. 2006;11(5):331-8. DOI: http://dx.doi. org/10.1159/000095819

15. Hong SM, Byun JY, Park CH, Lee JH, Park MS, Cha Cl. Saccular damage in patients with idiopathic sudden sensorineural hearing loss without vertigo. Otolaryngol Head Neck Surg. 2008;139(4):5415. DOI: http://dx.doi.org/10.1016/j.otohns.2008.07.003

16. Wu CC, Young YH. Vestibular evoked myogenic potentials are intact after sudden deafness. Ear Hear. 2002;23(3):235-8. PMID: 12072615 DOI:http://dx.doi.org/10.1097/00003446-200206000-00007

17. Ryu IS, Yoon TH, Ahn JH, Kang WS, Choi BS, Lee JH, et al. Three-dimensional fluid-attenuated inversion recovery magnetic resonance imaging in sudden sensorineural hearing loss: correlations with audiologic and vestibular testing. Otol Neurotol. 2011;32(8):1205-9. DOI:http://dx.doi.org/10.1097/MAO.0b013e31822e969f

18. Stamatiou G, Gkoritsa E, Xenellis J, Riga M, Korres S. Semicircular canal versus otolithic involvement in idiopathic sudden hearing loss. J Laryngol Otol. 2009;123(12):1325-30. DOI: http://dx.doi. org/10.1017/S0022215109990715

19. Kuo YL, Young YH. Hearing outcome of recurrent sudden deafness: ipsilateral versus contralateral types. Acta Otolaryngol. 2012;132(3):247-54. PMID: 22217185 DOI: http://dx.doi.org/10.3 109/00016489.2011.642817

20. Wang CT, Huang TW, Kuo SW, Cheng PW. Correlation between audiovestibular function tests and hearing outcomes in severe to profound sudden sensorineural hearing loss. Ear Hear. 2009;30(1):110 4. DOI: http://dx.doi.org/10.1097/AUD.0b013e318192655e

21. Jung JY, Kim YH, Suh MW. Difference in the nature of dizziness between vestibular neuritis and sudden sensorineural hearing loss with vertigo. Otol Neurotol. 2012;33(4):623-8. DOI: http://dx.doi. org/10.1097/MAO.0b013e318245cc86

22. Iwasaki S, Takai Y, Ito K, Murofushi T. Abnormal vestibular evoked myogenic potentials in the presence of normal caloric responses. Otol Neurotol. 2005;26(6):1196-9. DOI: http://dx.doi.org/10.1097/01. mao.0000194890.44023.e6

23. Iwasaki S, Takai Y, Ozeki H, Ito K, Karino S, Murofushi T. Extent of lesions in idiopathic sudden hearing loss with vertigo: study using click and galvanic vestibular evoked myogenic potentials. Arch Otolaryngol Head Neck Surg. 2005;131(10):857-62. PMID: 16230586 DOI:http://dx.doi.org/10.1001/archotol.131.10.857

24. Kang KT, Young YH. Sudden sensorineural hearing loss in a patient with primary antiphospholipid syndrome. J Laryngol Otol. 2008;122(2):204-6.

25. Chao TK, Hsiu-Hsi Chen T. Predictive model for improvement of idiopathic sudden sensorineural hearing loss. Otol Neurotol. 2010;31(3): 385-93. DOI:http://dx.doi.org/10.1097/MAO.0b013e3181cdd6d1 